\title{
Exchange Rate fluctuations and Financial Performance of Banks: Evidence from Sudan
}

\author{
Nawal Hussein Abbas Elhussein ${ }^{1}$ \& Osama Eltayeb Elfaki Osman ${ }^{2}$ \\ ${ }^{1}$ School of Management Studies, University of Khartoum, Khartoum, Sudan \\ ${ }^{2}$ Balad bank, Khartoum, Sudan \\ Correspondence: Nawal Hussein Abbas Elhussein, Mississauga, Ontario, L5B 3Z1, Canada. Tel: 1-289-724-2722. \\ E-mail: nawalelhussein80@gmail.com
}

Received: October 5, 2019

Accepted: October 25, 2019

Online Published: November 5, 2019

doi:10.5539/ijef.v11n12p15

URL: https://doi.org/10.5539/ijef.v11n12p15

\begin{abstract}
This paper aims at investigating whether fluctuations in the exchange rate affect the financial performance of Sudanese banks and detecting the direction of the causal relationship relation between exchange rate and banks' performance. The study targets a total population of 37 working banks in Sudan and covers the period 2002-2017. The sample comprises of the total set of the population. The paper depends mainly on secondary data, which is collected from consolidated financial reports of commercial banks and other official publications and documents. To test the hypotheses and accuracy and validity of models and data, a set of methods of data analysis are employed, namely, Ordinary Least Squared (OLS), Generalized Least Squares (GLS), Autoregressive Distributed Lag (ARDL) and a number of Diagnostic Tests. The study documents that foreign exchange rate fluctuations, contrary to empirical research findings, have a weak negative effect on Sudanese banks' financial performance. This may be attributed to the tight economic embargo against Sudan during the period of this study, which isolates the country from the international financial system and adversely affects its ability to engage in cross border activities. Consequently, the banking sector in Sudan is insulated from the effect of international currency movements and its exposure to currency risk that may create unpredictable profits and losses is minimal. In addition, the continuous deterioration of the Sudanese Pound and the limited FDI flows to the country render the investment environment uncompetitive and incapable of attracting foreign funds and the banking system of completely domestic nature.
\end{abstract}

Keywords: exchange rate, financial performance, lending rate, liquidity, return on assets, return on equity

\section{Introduction}

The exchange rate measures the value of one country's currency in terms of other currencies. Exchange rate fluctuations have been of a big concern to policymakers, regulators, investors, and financial analysts since the abolishment of the fixed exchange rate system of Bretton Woods in 1971. This system is replaced by different versions of floating exchange rate systems in which the price of a currency is determined mainly by supply and demand of that currency. Given the frequent changes in supply and demand for currencies, which is influenced by numerous economic factors, this new system is responsible for exchange rate fluctuations especially in developing economies, and Sudan is not an exception. Since its independence in 1956 a number of exchange rate policies have been implemented by monetary authorities in Sudan; ranging from fixed to floating exchange rate regimes. For instance, during the period 1956-1978 the central bank of Sudan has adopted a fixed exchange rate system, whereby the exchange rate has been pegged at a fixed rate of one Sudanese pound to 2.85 US dollar. Since 1979 the country shifted to a flexible exchange rate system which has resulted in continuous exchange rate devaluations and government interventions. In the early nineteen nineties the government announced the economic liberalization policy during which market mechanism is selected as a tool for setting exchange rates. This policy was abolished three years later and replaced by establishing two windows for exchange rate dealings; commercial bank exchange rate dealings in which the exchange rate is devalued to 3 pounds /US\$ and a window of the central bank in which the exchange rate is devalued to 2.15 pounds /US\$. During the period 2000-2006 and as a result of foreign currency inflows associated with Sudan petroleum exports, the foreign exchange market was unified with a sole exchange rate of 2.6 Sudanese pounds for the dollar. The exchange rate, then, kept on deteriorating at an accelerating rate throughout the period 2006-2017; from 2.6 to 6.9 US dollars, with 
many interventions and devaluations of currency by the central bank. For instance, in 2012 the Sudanese pound was devalued by $91 \%$ in one step, from 2.67 to 4.42 pounds for the dollar to minimize the difference between the official and parallel rates. Nevertheless the problem continues and the difference between the parallel and official exchange rates continued to escalate to reach 184 percent of the parallel rate by the end of 2017 .

The importance of the exchange rate has been tremendously discussed in the literature due to its key role in enhancing the competitiveness of a country in the international economy and strengthening its inward financial stability. In addition to its vital impact on foreign investment, trade patterns, exports of goods, and trade balance exchange rate movements affect corporate performance through impacting their expected cash flows and ultimately their profitability. Given the importance of the banking system to the economy, it is very important to comprehend how the performance of this sector is affected by foreign currency fluctuations. Banking operations have significant implications for credit to the domestic economy, internal reserves, intermediation in the investment process and ultimately economic growth of countries. Banks are one of the leading actors in the foreign exchange market; they engage in import and export activities, the transactions of which must be paid for in foreign currencies. Banks also participate in foreign exchange markets as intermediaries for business organizations that operate internationally. Thus banks' financial performance which, refers to the ability to leverage operational and investment decisions and strategies to achieve profitability and financial stability, is largely affected by exchange rate fluctuations. Fluctuations in currency exchange rates could generate significant gains or losses, which in turn may produce distorted financial results and give wrong impression of the financial position of the institution concerned. Further foreign exchange rate movements could be an important source of risk for banking institutions if not well managed or hedged. Thus due to its serious implications for banking sector stability, measuring the impact of foreign exchange exposure on financial performance of commercial banks has long been a core interest of academics, professionals, bankers and policy makers. A large number of empirical studies have been carried out regarding this issue in well-developed banking markets as well as in developing settings.

This study empirically examines the impact of foreign exchange rate fluctuations on the Sudanese banking sector performance in an attempt to investigate whether these fluctuations affect the financial performance of banks and what is the type and direction of relationship between exchange rate movements and banks' financial performance. The rest of this paper is outlined as follows: Section two provides a review of the literature that researches the relationship between exchange rate volatility and banking sector performance. Section three describes the methodology used. Section four presents the empirical results. In section five the results are thoroughly discussed. Section six concludes the paper.

\section{Literature Review}

The banking sector contributes immensely to the economic growth of countries, especially those with limited and underdeveloped capital markets, by making funds available for investment. The importance of bank performance can be appraised at the micro and macro levels of the economy. At the micro level bank profitability is an essential prerequisite for a successful, competitive institution that is capable of offering source of funds at a lower cost. At the macro level a profitable banking sector is a buffer that resists negative economic shocks and contributes to the stability of the financial system. The relationship between bank sector performance and macroeconomic environment has always been emphasized in the literature and the lesson learned from recurring financial crises is that banking sector performance and its resilience depend on the standing of the macroeconomic environment. Macroeconomic chocks, such as great variability of economic growth, fluctuations of exchange rate and instability of inflation have led to banking crises and bankruptcies. Equally favorable or unfavorable banks performance induces expansion or contraction of credit, which in turn leads to or amplifies macroeconomic shocks. A number of theoretical models which has been developed to assess bank performance and its impact on the economy indicate that there is an interaction between banking performance, solvency risk and macroeconomic indicators, such as gross domestic product, inflation and exchange rate. Further, these studies conclude that banking crises are very costly for the economy and require decisions ranging from enacting new laws up to bailing out of banks. The substantial commitments incurred by the US government after the 2008 financial crises, in terms of loans, guarantees, and other bailout funding to address the credit and liquidity crunch and stabilize the deteriorating financial system is a good example.

Studies on foreign exchange rate fluctuations and their impact on different aspects of the economy have gained much attention in the literature. The association between foreign exchange rate variations and banking sector performance is a current issue in this respect. The relationship between bank performance and macroeconomic factors specifically GDP, interest rate, inflation and market concentration has been comprehensively researched. However, fewer empirical researches have addressed the foreign exchange exposure of banks and whether it 
affects their profitability. Some of these researches discuss the influence of the exchange rate on banking sector performance within the context of internal and external determinants of banks performance. Others concentrate only on the impact of exchange rate fluctuations on performance. There seems to be a general consensus among these researches that exchange rate volatility does have an impact on banks performance. However, the direction of relationship documented between the two variables differs. For instance Chamberlain, Howe, and Popper (1997), Ngerebo (2011), Babazadeh and Farrokhnejad (2012), Acaravci and Çalim (2013), Chisepeya (2014), Osuagwu (2014), He, Fayman, and Casey (2014), Issac (2015), Lagat and Nyandema (2016) and Saona (2016) report a significant positive relationship between exchange rate fluctuations and profitability of banks. A significant negative relationship is confirmed by Taiwo and Adesola (2013), Getachew (2014), Osuagwu (2014), Offiong, Riman, and Akpan (2016), Kemisola, Ademola, Olamide, and Moses (2016), Combey and Togbenou (2017), Almaqtari, Al - Homaidi, Tabash and Farhan (2018) and -Hasanov, Bayramli and Al-Musehel (2018). In all these studies profitability of banks is generally measured by Return on Asset (ROA), Return on Equity (ROE) and Net Interest Margin (NIM). The ROA, which is the ratio of net income to total assets, measures how profitably and efficiently the management is using the firm's total assets. On the other hand, the ROE, which is the ratio of net income to total equity shows the return to shareholders on their investments. The NIM is defined as the net interest income divided by total assets and emphasizes profit earned on interest activities. The methodologies used in carrying out these researches vary, including time-series model and cross-sectional model estimated using Ordinary Least Squares (OLS), Least squares methods of fixed effects (FE) and random effects (RE) models, Dickey-Fuller (ADF) test, Error Correction Model (ECM), Generalized Method of Moments (GMM) and Autoregressive Distributed Lag Model (ARDL).

An important point to note about the results of these studies is the somewhat confusing or mixed evidence of direction of relationship between bank performance and exchange rate movements. Researches that cover developed economies show consistent outcomes, namely, a significant positive relationship between exchange rate fluctuations and profitability of banks. Conversely, some of the researches carried out in developing countries conclude that exchange rate and banks' profitability are directly related while others infer that the relation is an inverse one. These mixed results are justified on the basis of measures of bank performance used and factors which are either country specific or bank specific. As stated by Kemisola et al. (2016), the effect of exchange rate fluctuation on banks performance is materially affected by the specific measure used to judge the bank performance. According to Almaqtari et al. (2018), extent of deterioration of local currency as compared to other foreign currencies may be a reason. Razi et al. (2012) noted that magnitude of foreign direct investment may affect the extent and direction of association between exchange rare and bank profitability. Also bank size has been cited by Wong et al. (2009) as a determinant of the direction of the sigh of the relationship between foreign exchange and bank profitability.

Based on this literature review the paper formulae and tries to answer the following questions: Do fluctuations in the exchange rate affect the financial performance of Sudanese banks? What is the type of such impact if any? Is it positive or negative? What is the direction of the causal relationship relation between fluctuations in exchange rates and banks' financial performance in Sudan? To answer these questions the research tests the following hypotheses: (H0): exchange rate fluctuations have no significant impact on the banking financial performance in Sudan and (H1): exchange rate fluctuations have a significant impact on the banking financial performance in Sudan.

\section{Methods}

The study targets a total population of 37 working banks in Sudan and covers the period 2000-2017. The sample comprises of the total set of the population. The paper depends mainly on secondary data, which is collected from consolidated financial reports of commercial banks. Official publications and documents of the Central Bank of Sudan, the Ministry of Finance, the Statistical Bureau of Sudan and the World Bank also constitute a source of the research data. To test the hypotheses and the accuracy and validity of models and data, a set of methods of data analysis are employed, namely, Ordinary Least Squared (OLS), Maximum Likelihood Estimation (MLE), Generalized Least Squares (GLS), Autoregressive Distributed Lag(ARDL) and a number of Diagnostic Tests. Data is examined to make sure that it is good for building the model and driving reliable and verifiable results. Three models are developed to test the relation between exchange rate fluctuations and financial performance of Sudanese banks. The analysis is conducted through the use of Eviews program.

Data is tested for serial correlation, heteroscedasticity and Normality using correlogram and Q-statistics, White's Test and Jarque-Bera test respectively. Though trade-off between profit and liquidity is an important goal of any business firm, this trade-off is more prevalent for banks, so profitability and liquidity are considered by this study as important measures of banks financial performance. The econometric model of this functional 
relationship between variables is given by the following equation:

$$
Y i=\alpha+\beta i X i+\mu
$$

Where:

$\mathrm{Yi}=$ banking sector financial performance indicators.

$\mathrm{Xi}=$ exchange rate fluctuations and controlling variables.

$\alpha=$ Autonomous constant

$\beta \mathrm{i}=$ Coefficients of independent variables;

$\mu=$ Error terms.

The main model of the research is stated as follows:

$$
L Q T Y+R O A+R O E=\alpha+\beta 1 E X F+\beta 2 N E X+\beta 3 F D I+\beta 4 L D R+\mu .
$$

Where:

LOTY: represents Banking liquidity Ratio which is calculated by dividing bank credit to the private sector (CRE) by the share of banks' deposits (DEP) (CRE/DEP \%). CRE represents the general level of loans provided by the banking sector. The share of banks' deposits (DEP) provides the extent of access and deposit mobilization the banking sector offers, ROA: is the proxy for banking profitability, ROE: is the measure of the efficiency of banks to finance potential investment projects, EXRF: represents foreign exchange rate fluctuations, which is measured by the difference between parallel and official exchange rates, NEX: is the net of foreign trade (exports imports), which is a fundamental determinant of exchange rates and balance of payment, FDI: is the foreign direct investment, LDR: represents lending rate as the cost of financing in Islamic Banking Systems.

This main model has been divided into three models.

$$
\begin{gathered}
\text { ROE model: } R O E=\alpha+\beta 1 E X F+\beta 2 N E X+\beta 3 F D I+\beta 4 L D R+\mu \\
\text { ROA model: } R O A=\alpha+\beta 1 E X F+\beta 2 N E X+\beta 3 F D I+\beta 4 L D R+\mu \\
\text { Liquidity (LQTY) model: } L Q T Y=\alpha+\beta 1 E X F+\beta 2 N E X+\beta 3 F D I+\beta 4 L D R+\mu
\end{gathered}
$$

The study uses many tools for evaluating the quality of its specification model along with a number of measurements such as stability tests, coefficient diagnostics and residual diagnostics. The results of these tests influence the chosen specification. Each test procedure involves the specification of a null hypothesis, which is the hypothesis under examination. Output from a test command consists of the sample values of one or more test statistics and their associated probability numbers (p-values). The latter indicate the probability of obtaining a test statistic whose absolute value is greater than or equal to that of the sample statistic if the null hypothesis is true. Low p-values lead to the rejection of the null hypothesis; if a p-value is less than 0.05 then the null hypothesis will be rejected.

The ARDL model is used to test for cointegration, and estimate long-run dynamics of the dependent and independent variables. The ARDL Bounds Testing methodology of Pesaran and Shin (1999) and Pesaran et al.. (2001) has been applied. The analysis involves testing that none of the variables are $I(2)$, determining the appropriate lag structure for the model, making sure that the errors of the model are serially independent, showing that the model is dynamically stable and performing a Bound Test to see if there is evidence of a long-run relationship between the variables.

\section{Results}

Descriptive statistics and correlation matrix are employed by the study to provide insight into the characteristics of data in order to enable the best selection of the model. The descriptive statistics presented in Table (1) show that the seven variables exhibit positive means, and varying unconditional volatility. The skewness and high values of kurtosis coefficients imply that the distributions of these variables are characterized by peakness relative to a normal distribution. The Jarque-Bera (JB) test statistic provides p-values less than 0.05 , thus the null hypothesis of normality is rejected. Table 2 presents the correlation matrix between the variables considered with their significance levels. The matrix reveals that there is no perfect collinearity that hinders the model estimation. 
Table 1. Descriptive statistics

\begin{tabular}{lccccccc}
\hline & EXRF & FDI & LDR & LQTY & NEX & ROA & ROE \\
\hline Mean & 0.8615 & 116102 & 8.0698 & 1.8347 & 133418 & 9.0720 & 2.8986 \\
Median & 0.08 & 961700 & 7.6 & 1.9832 & 131425 & 8.6022 & 3.0472 \\
Maximum & 5.18 & 314904 & 24 & 4.5807 & 153298 & 25.002 & 5.6447 \\
Minimum & 0.01 & 143271. & 2.35 & 0.5818 & 123240 & 3.3522 & 1.6458 \\
Std. Dev. & 1.3077 & 717387. & 4.3258 & 0.6197 & 717387 & 4.3258 & 0.6197 \\
Skewness & 1.4468 & 0.99370 & 0.9612 & 0.9030 & 0.9937 & 0.9612 & 0.9030 \\
Kurtosis & 3.9689 & 3.45475 & 4.4923 & 7.8375 & 3.4547 & 4.4923 & 7.8375 \\
Jarque-Bera & 24.444 & 10.9111 & 15.547 & 69.993 & 10.911 & 15.547 & 69.993 \\
Probability & 0.0000 & 0.00427 & 0.0004 & 0000 & 0.0042 & 0.0004 & 0000 \\
Sum & 54.28 & 731448 & 508.4 & 115.58 & 8.41 & 571.53 & 182.61 \\
Sum Sq. Dev. & 106.03 & 3.19 & 1160.1 & 23.816 & 3.19 & 1160.1 & 23.816 \\
Observations & 63 & 63 & 63 & 63 & 63 & 63 & 63 \\
\hline
\end{tabular}

Researcher's Eviews output.

Table 2. Correlation matrix

\begin{tabular}{|c|c|c|c|c|c|c|c|}
\hline & LEXRF & LFDI & LLDR & LNEX & LLQTY & LROA & LROE \\
\hline LEXRF & 1 & & & & & & \\
\hline \multirow[t]{2}{*}{ LFDI } & 0.71718 & 1 & & & & & \\
\hline & 8.03778 & ----- & & & & & \\
\hline \multirow[t]{3}{*}{ LLDR } & -0.1579 & -0.06882 & 1 & & & & \\
\hline & -1.2489 & -0.53874 & ----- & & & & \\
\hline & 0.2165 & 0.592 & ----- & & & & \\
\hline \multirow[t]{3}{*}{ LNEX } & -0.6335 & -0.63996 & -0.1640 & 1 & & & \\
\hline & -6.3959 & -6.5047 & -1.2990 & ----- & & & \\
\hline & 0 & 0 & 0.1988 & ----- & & & \\
\hline \multirow[t]{3}{*}{ LLQTY } & 0.58511 & 0.79982 & -0.2832 & -0.33817 & 1 & & \\
\hline & 5.63520 & 10.4073 & -2.3069 & -2.80649 & ----- & & \\
\hline & 0 & 0 & 0.0245 & 0.0067 & ----- & & \\
\hline \multirow[t]{3}{*}{ LROA } & -0.1619 & -0.07498 & 0.99924 & -0.1589 & -0.2896 & 1 & \\
\hline & -1.2819 & -0.58723 & 200.684 & -1.25705 & -2.3637 & ----- & \\
\hline & 0.2047 & 0.5592 & 0 & 0.2135 & 0.0213 & ----- & \\
\hline \multirow[t]{3}{*}{ LROE } & 0.60433 & 0.75602 & -0.2743 & -0.34773 & 0.9594 & -0.2816 & 1 \\
\hline & 5.92414 & 9.021026 & -2.2280 & -2.89666 & 26.575 & -2.292 & ----- \\
\hline & 0 & 0 & 0.0296 & 0.0052 & 0 & 0.0253 & ----- \\
\hline
\end{tabular}

Researcher's Eviews output.

To avoid spurious regression the paper tests the variables for stationarity before running regression. The findings of Augmented Dickey Fuller (ADF) test and Philip Peron unit root shown in Table 3 reveal that the null hypothesis of a unit root at level 5\% significance level is rejected for all variables except EXRF and NEX for which the null hypothesis cannot be rejected.

Table 3. Stationary tests

\begin{tabular}{|c|c|c|c|c|}
\hline \multirow[t]{2}{*}{ Variables } & \multicolumn{2}{|c|}{$\mathrm{ADF}$} & \multicolumn{2}{|c|}{ PPT } \\
\hline & Level & $\begin{array}{c}\text { Prob. } \\
\text { First diff. }\end{array}$ & Level & $\begin{array}{c}\text { Prob. } \\
\text { First diff }\end{array}$ \\
\hline EXRF & 1 & .0000 & 1 & .0000 \\
\hline FDI & .0249 & .0000 & .6381 & .0000 \\
\hline LDR & .0386 & .0001 & .0000 & .0001 \\
\hline LQTY & .0373 & .0000 & .0045 & .0001 \\
\hline NEX & .999 & .0000 & .6381 & .0000 \\
\hline ROA & .0381 & .0001 & .0000 & .0000 \\
\hline ROE & .0386 & .0000 & .0045 & .00 \\
\hline
\end{tabular}

Researcher's Eviews output. 
To check specification of the estimated equations tests for auto correlation, serial correlation, normality, and heteroskedasticity are carried out for the research data. As for heteroskedasticity, the Breusch-Pagan-Godfrey tests reveal that the ROE and LQTY do not face any problem of heteroskedasticity, whereas the ROA model faces such a problem. The three models suffer serial correlation and non normality. No autocorrelation is detected in any of the three models. Results of these tests are displayed in Appendix (A). The study applies the lagged model and the ARIMA models to correct the research models from the statistical problems they undergo. The results of the tests reveal that the problems of serial correlation and heteroskedasticity have been solved in the three models. To check the stability of these models the study applies Cusum Test. From figures 1, 2 and 3 it appears that the cumulative sum of recursive residuals lies inside the area between two critical lines, which suggests that the dependent variables of the research three models are stable.

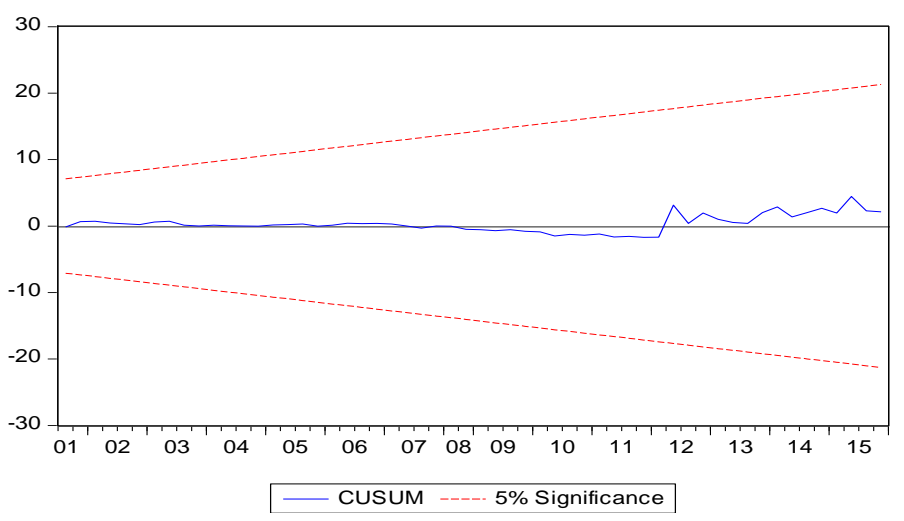

Figure 1. A Stability Test for ROE

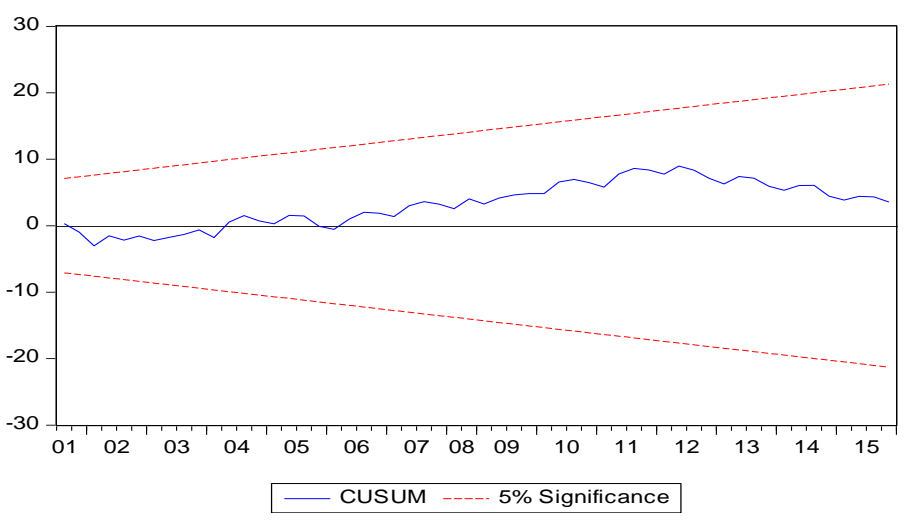

Figure 2. A Stability Test for ROA

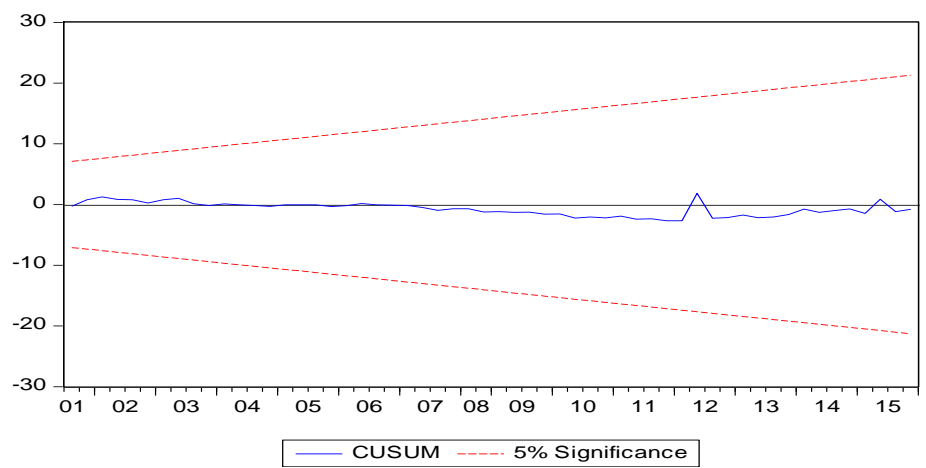

Figure 3. Stability Test for LQTY 


\subsection{Test of Hypotheses}

The research uses the data collected to test the hypotheses that $\mathrm{H} 0: \beta_{1}=0, \beta 2=0 \ldots \beta_{\mathrm{n}}=0$, which means that the research rejects the null hypothesis of coefficients excluding intercepts are equal to zero. The study applies the t-test and F-test the results of which confirm that each coefficient does not equal zero. Thus the study concludes that all independent variables do have effect on the dependent variables. A summary of values of coefficients of regressors in each model are presented in table 4.

Table 4. Summary of values of coefficients of regressors

\begin{tabular}{cccccc}
\hline & ROE & & \multicolumn{2}{c}{ ROA } & \multicolumn{2}{c}{ LQTY } \\
\hline coefficient & value & coefficient & value & coefficient & value \\
\hline$\beta$ EXRF & -0.008116 & $\beta$ EXRF & -0.209639 & $\beta$ EXRF & -0.012880 \\
$\beta$ LDR & -0.006477 & $\beta$ LDR & 0.327642 & $\beta$ LDR & -0.009824 \\
$\beta$ FDI & $4.30 \mathrm{E}-08$ & $\beta$ FDI & -0.004698 & $\beta$ FDI & $1.66 \mathrm{E}-08$ \\
$\beta$ NEX & $-2.45 \mathrm{E}-07$ & $\beta$ NEX & -0.020628 & $\beta$ NEX & $4.19 \mathrm{E}-06$ \\
\hline
\end{tabular}

Researcher's Eviews output.

The results of the analysis of using the research three models regarding the impact of exchange rate fluctuations on the financial performance of Sudanese banks are estimated and presented in tables 5, 6 and 7.

Table 5. Coefficients estimation outputs for ROE Model Parameters

\begin{tabular}{ccccc}
\hline Variable & Coefficient & Standard error & t-statistic & Probability \\
\hline C & -0.547550 & 0.224736 & -2.436414 & 0.0182 \\
EXRF & -0.002550 & 0.021660 & -0.117718 & 0.9067 \\
LDR & -0.076238 & 0.045823 & -1.663757 & 0.1020 \\
FDI & 0.177969 & 0.036336 & 4.897895 & 0.0000 \\
NEX & $-4.61 \mathrm{E}-08$ & $3.49 \mathrm{E}-06$ & -0.013195 & 0.9895 \\
\hline
\end{tabular}

Researcher's calculations conducted with Eviews software.

Table 6. Coefficients estimation outputs for ROA Model Parameters

\begin{tabular}{ccccc}
\hline Variable & Coefficient & Standard error & t-statistic & Probability \\
\hline C & -0.209639 & 46.66041 & -0.004493 & 0.9964 \\
EXRF & -0.004482 & 0.015246 & -0.293969 & 0.7699 \\
LDR & 0.327642 & 0.097402 & 3.363805 & 0.0014 \\
FDI & -0.004698 & 0.046057 & -0.102009 & 0.9191 \\
NEX & -0.020628 & 0.037291 & -0.553158 & 0.5824 \\
\hline
\end{tabular}

Researcher's calculations conducted with Eviews software.

Table 7. Coefficients estimation outputs for LQTY Model Parameters

\begin{tabular}{ccccc}
\hline Variable & Coefficient & Standard error & t-statistic & Probability \\
\hline C & 0.203023 & 46.38480 & 0.004377 & 0.9965 \\
EXRF & -0.012880 & 0.018759 & -0.686625 & 0.4953 \\
LDR & -0.009824 & 0.004556 & -2.156246 & 0.0355 \\
FDI & $1.66 \mathrm{E}-08$ & $1.92 \mathrm{E}-08$ & 0.863929 & 0.3914 \\
NEX & $4.19 \mathrm{E}-06$ & $3.06 \mathrm{E}-06$ & 1.369129 & 0.1766 \\
\hline
\end{tabular}

Researcher's calculations conducted with Eviews.

From the coefficients for ROE model parameters, it can be concluded that the fluctuations of exchange rate have a negative and statistically insignificant effect on the profitability of financial performance of Sudanese banks; a coefficient of - 0.0025. The other independent variables, LDR, FDI and NEX also have small effect on the profitability as a proxy of financial performance for Sudanese bank with coefficients of $-0.076,0.178$ and -4.61 respectively.

As regarding ROA model the results also indicate the negative and insignificant impact of fluctuations of exchange rate on the profitability of Sudanese banks; a one unit increase in the exchange rate will change ROA 
by -0.0045 unit. Similarly the effect of FDI and NEX is a minor one. However LDR has a positive and statistically significant impact on ROA. The coefficients in table 7 as well confirm the small and negative effect of exchange rate fluctuations on the liquidity of Sudanese banks; a coefficient of -0.0129 . The effect of the LDR on LQTY is the same as on ROE, negative and small; a coefficient of -0.001 .

The goodness of the models is ascertained by the values of R-squared and F-statistics for each model. As shown in Appendix (B) R-squared equals 0.64682 for ROE model which means $64.7 \%$ of variation in the dependent variable is explained by the independent variables. Similarly the R-squared values for ROA model and LQTY model indicate that the models explain $60 \%$ and $83 \%$ of the financial performance of Sudanese banks respectively. The Probability of the F-statistic is equal to zero in each of the three models, which reveals that the models are statistically significant.

To examine the presence of long-run relationship between the exchange rate fluctuations and the independent variables the ARDL Model is used to test for cointegration, and estimate long-run and short-run dynamics. From the ARDL Bounds tests shown in tables 8, 9 and 10 it is clear that the null hypothesis that no long-run relationship exist between the variables is rejected which, confirms the long run relationship between the dependent and independent variables. The coefficients are (-0.916599), (-2.265046) and $(-0.212618)$ for ROE, ROA and LQTY models respectively and the $\mathrm{p}$ values are equal to the zero in the three models.

Table 8. ARDL bounds test (ROE Model)

\begin{tabular}{|c|c|c|c|c|c|}
\hline \multicolumn{6}{|c|}{ ARDL Bounds Test } \\
\hline \multicolumn{6}{|c|}{ Null Hypothesis: No long-run relationships exist } \\
\hline Test Statistic & & Value & & $\mathrm{K}$ & \\
\hline F-statistic & & 8.180171 & & 4 & \\
\hline \multicolumn{6}{|c|}{ Critical Value Bounds } \\
\hline Significance & & I0 Bound & & I1 Bound & \\
\hline $10 \%$ & & 2.45 & & 3.52 & \\
\hline $5 \%$ & & 2.86 & & 4.01 & \\
\hline $2.5 \%$ & & 3.25 & & 4.49 & \\
\hline $1 \%$ & & 3.74 & & 5.06 & \\
\hline Variable. & Coefficient & & Std. Error & -Statistic & Prob \\
\hline CointEq(-1) & -0.916599 & & 0.137909 & -6.646420 & 0.0000 \\
\hline
\end{tabular}

Cointeq $=$ LROE $-(-0.0030 *$ LEXRF $+0.0295 *$ LFDI $-0.7034 *$ LLDR $-0.0712 *$ LNEX +1.1620$)$

Researcher's E-views Output.

Table 9. ARDL bounds test (ROA Model)

\begin{tabular}{|c|c|c|c|c|c|}
\hline \multicolumn{6}{|c|}{ ARDL Bounds Test } \\
\hline \multicolumn{6}{|c|}{ Null Hypothesis: No long-run relationships exist } \\
\hline \multicolumn{2}{|c|}{ Test Statistic } & \multicolumn{2}{|l|}{ Value } & \multicolumn{2}{|l|}{$\mathrm{K}$} \\
\hline \multicolumn{2}{|l|}{ F-statistic } & \multicolumn{2}{|l|}{30.18038} & \multicolumn{2}{|l|}{4} \\
\hline \multicolumn{6}{|c|}{ Critical Value Bounds } \\
\hline Significance & & I0 Bound & & I1 Bound & \\
\hline $10 \%$ & & 2.45 & & 3.52 & \\
\hline $5 \%$ & & 2.86 & & 4.01 & \\
\hline $2.5 \%$ & & 3.25 & & 4.49 & \\
\hline $1 \%$ & & 3.74 & & 5.06 & \\
\hline Variable. & Coefficient & & Std. Error & -Statistic & Prob \\
\hline CointEq(-1) & -0.916599 & & 0.137909 & -6.646420 & 0.0000 \\
\hline
\end{tabular}

Cointeq $=$ Cointeq $=$ LROA $-(0.0009 *$ LEXRF $+0.0010 *$ LFDI $+0.8725 *$ LLDR +0.0045$)$

Researcher's E-views Output. 
Table 10. ARDL bounds test (ROE Model)

\begin{tabular}{|c|c|c|c|c|c|}
\hline \multicolumn{6}{|c|}{ ARDL Bounds Test } \\
\hline \multicolumn{6}{|c|}{ Null Hypothesis: No long-run relationships exist } \\
\hline \multicolumn{2}{|l|}{ Test Statistic } & \multicolumn{2}{|l|}{ Value } & \multicolumn{2}{|l|}{$\mathrm{K}$} \\
\hline \multicolumn{2}{|l|}{ F-statistic } & \multicolumn{2}{|l|}{30.18038} & \multicolumn{2}{|l|}{4} \\
\hline \multicolumn{6}{|c|}{ Critical Value Bounds } \\
\hline \multicolumn{2}{|l|}{ Significance } & \multicolumn{2}{|l|}{ I0 Bound } & \multicolumn{2}{|l|}{ I1 Bound } \\
\hline \multicolumn{2}{|l|}{$10 \%$} & \multicolumn{2}{|l|}{2.45} & \multicolumn{2}{|l|}{3.52} \\
\hline \multicolumn{2}{|l|}{$5 \%$} & \multicolumn{2}{|l|}{2.86} & \multicolumn{2}{|l|}{4.01} \\
\hline \multicolumn{2}{|l|}{$2.5 \%$} & \multicolumn{2}{|l|}{3.25} & \multicolumn{2}{|l|}{4.49} \\
\hline \multicolumn{2}{|l|}{$1 \%$} & \multicolumn{2}{|l|}{3.74} & \multicolumn{2}{|l|}{5.06} \\
\hline Variable. & Coefficient & & Std. Error & -Statistic & Prob \\
\hline CointEq(-1) & -0.916599 & & 0.137909 & -6.646420 & 0.0000 \\
\hline \multicolumn{6}{|c|}{ Cointeq $=$ LLQTY $-(-0.0184 *$ LEXRF $+0.0020 *$ LFDI $+0.2116 *$ LLDR $+0.0419 *$ LNEX-0.0100) } \\
\hline
\end{tabular}

Researcher's E-views Output.

\section{Discussion}

Though the exchange rate is expected to have a significant effect on the profitability and liquidity of banks, whether positive or negative as empirical studies report, to the contrary this paper finds that foreign exchange rate fluctuations have a weak negative effect on Sudanese banks financial performance. The same result is arrived at by using ROE, ROA or Liquidity as a measure of performance, which negates the argument that the effect of exchange rate fluctuation on banks performance is materially affected by the specific performance measure used. Country specific factors which have been cited as a reason for mixed results regarding this issue can be a justifiable rationale for the weak effect of foreign exchange rate on Sudanese banks financial performance. The country has been under tight economic embargo that continues for almost three decades. All Sudanese banks and other credit and financial institutions have suffered greatly from this embargo, which isolates them from the international financial system and hence adversely affects their ability to engage in cross border activities. As a result the banking sector in Sudan is insulated from the effect of international currency movements and its exposure to currency risk that may create unpredictable profits and losses is minimal. According to Almaqtari et al. (2018), extent of deterioration of local currency as compared to other foreign currencies could be a reason for contradicting study results. The persistent worsening of the Sudanese Pound against the US dollar leads to a continuous devaluation of the national currency and changing, unstable fiscal and financial policies. This renders the investment environment unappealing and incapable of attracting foreign capital flows. Further, the size of foreign direct investment, which is cited in the literature as a factor that may affect the extent and direction of association between exchange rate and bank profitability is clearly apparent in the case of Sudan. Though there are no administrative restrictions on foreign investment in Sudan, flows of FDI to the country are very limited; ranging between 4\% to $0.9 \%$ of GDP during the ten year period 2007-2017 (https://www.ceicdata.com/en/indicator/sudan/foreign-direct-investment--of-nominal-gdp). Attracting investment is a competitive exercise which requires stable, sound macroeconomic policies, which lend confidence to take the risk inherent in investing capital. Consequently the banking system becomes of almost completely domestic nature; with transactions executed in foreign currencies being settled by customers in local currencies and foreign trade transfers being done outside the banking sector. This justifies the insignificant impact of exchange rate fluctuations on banks' profitability. Also the positive and statistically significant impact of the lending rate on ROA reflects the dependence of Sudanese banking sector on investment in local currency.

The generalizability or external validity of these results may be limited due to the lack of a fairly consistent long time series data; the study covers the period 2002-2017 using quarterly data. This may limit the generality of the results as statistical tests normally require a larger sample size to ensure a representative distribution of the population and generalization of outcomes. As well, research with a wider time span would be imperative in assessing the independent variables against the dependent variables. Further the paper uses the US dollar as the yardstick to measure foreign exchange fluctuations. Usage of other international currencies such as the Sterling Pound or the Euro to measure the Sudanese currency fluctuations, usage would confirm the impact of foreign exchange fluctuations on performance regardless of the hard currency being employed.

\section{Conclusions}

This study seeks to investigate whether fluctuations in exchange rate affect the financial performance of 
Sudanese banks and identify the extent and direction of relationship between the exchange rate and banks' performance. Utilizing data that covers the ten-year period 2002-2017 and a sample of 37 banks, the study develops three models to examine the relationship between fluctuations in exchange rate and indicators of financial performance. The analysis involves employing a number of statistical methods to determine the impact of each of the independent variables; EXRF, FDI, LDR and NEX on the financial performance of banks in Sudan using ROA and ROE to measure profitability and deposits to loans ratio (LQTY) as a proxy for liquidity. Many statistical techniques have been applied to test the validity of data and estimate and correct the models developed by the study. Based on the results of the analysis, which are generated by Eviews 9 package and statistical values obtained through computations, the study finds an inverse insignificant relationship between fluctuations in the exchange rate and the financial performance indicators of the Sudanese banks. The other independent variables are also found to have a minor effect on Sudanese banks' performance. The findings seem to contradict what is evidenced by literature which reports significant impact of the exchange rate on the profitability and liquidity of banks, whether positive or negative. Country specific factors, extent of deterioration of local currency as compared to other foreign currencies and the size of foreign direct investment are asserted as reasons for study results. The tight economic embargo against the country that continues for almost three decades, the worsening of the Sudanese Pound against the US dollar which leads to a continuous devaluation of the national currency and the limited FDI flows render the investment environment uncompetitive and incapable of attracting foreign investors. The result being a banking system of nearly totally domestic nature, which justifies the insignificant impact of exchange rate fluctuations on banks' profitability.

The outcome of this study could be of practical significance to the monetary and fiscal authorities in Sudan. It brings to sight the pressing need for developing and setting policies to mitigate the tight effect of the economic embargo. Such policies should concentrate on controlling inflation, reducing the cost of funds, encouraging foreign investors by providing them incentives such as tariff concessions and tax reliefs to attract their transfers into the banking system. The Central Bank should strive to put measures to safeguard the value of the domestic currency such as having enough reserves in foreign currencies, encouraging exports and reducing the gap between the official and parallel rates. The real solution, however, will be in achieving the country's sustainable peace and political reform which will ensure national security and political stability required for creating an attractive investment environment.

\section{References}

Acaravci, S., \& Çalim, A. (2013). Turkish banking sector's profitability factors. International Journal of Economics andFinancial Issues, 3(1), 27-41.

Ahmed, L. (2015). The Effect of Foreign Exchange Exposure on the Financial Performance of Commercial Banks in Kenya. International Journal of Scientific and Research Publications, 5(11), 115-120.

Almaqtari, F., Al - Homaidi, E., Tabash, M., \& Farhan, N. (2018). The determinants of profitability of Indian commercial banks: A panel data approach. International Journal of Finance and Economics, 24(1), 168-185. https://doi.org/10.1002/ijfe.1655

Athanasoglou, P., Brissimis, S., \& Delis, M. (2008). Bank-specific, industry-specific and macroeconomic determinants of bank profitability. Journal of International Financial Markets, Institutions and Money, 18(2), 121-136. https://doi.org/10.1016/j.intfin.2006.07.001

Babazadeh, M., \& Farrokhnejad, F. (2012). Effects of Short-run and Long-run Changes in Foreign Exchange Rates on Banks' Profit. International Journal of Business and Management, 7, 70-77. https://doi.org/10.5539/ijbm.v7n17p70

Chamberlain, S., Howe, J., \& Popper, H. (1997). The Exchange Rate Exposure of U.S. and Japanese Banking $\begin{array}{llll}\text { Institutions. Journal of Banking and } & \text { Finance, 21(6), }\end{array}$ https://doi.org/10.1016/S0378-4266(97)00002-2

Chisepeya, E. (2013). Effects of the Currency Exchange Rate on Performance of Commercial Banks in Malawi. (Unpublished master's thesis), University of Malawi, Malawi.

Choi, I. (2001). Unit Root Tests for Panel Data. Journal of International Money and Finance, 20, 249-72. https://doi.org/10.1016/s0261-5606(00)00048-6

Combey, A., \& Togbenou, A. (2017). The Bank Sector Performance and Macroeconomics Environment: Empirical Evidence in Togo. International Journal of Economics and Finance, 9(2), 180-188. https://doi.org/10.5539/ijef.v9n2p180 
Flamini, V., McDonald, C., \& Schumacher, L. (2009). The Determinants of Commercial Bank Profitability in Sub-Saharan Africa. IMF Working Paper 09/15, January 2009. https://doi.org/10.5089/9781451871623.001

Garcia, M., \& Guerreiro, J. (2016). Internal and external determinants of banks' profitability: The Portuguese case. Journal of Economic Studies, 43(1), 90-107. https://doi.org/10.1108/JES-09-2014-0166

Getachew, T. (2015). The Impact of Exchange Rate on the Profitability of Commercial Banks in Ethiopia. College of business and economics, Addis Ababa University.

Granger, C. (1969). Investigating causal relations by error-correction models and cross-spectral methods. Econometrica, 37(3), 424-438. https://doi.org/10.2307/1912791

Granger, C. (1988). Some recent developments in a concept of causality. Journal of Econometrics, 39, 199-211. https://doi.org/10.1016/0304-4076(88)90045-0

Gul, S., Faiza, I., \& Khalid, Z. (2011). Factors Affecting Bank Profitability in Pakistan. The Romanian Economic Journal, 2(3), 6-9.

Hasanov, F., Bayramli, N., \& Al-Musehel, N. (2018). Bank-Specific and Macroeconomic Determinants of Bank Profitability: Evidence from an Oil-Dependent Economy. International Journal of Financial Studies, 6(2), 78; https://doi.org/10.3390/ijfs6030078

He, L., Fayman, A., \&Casey, K. (2014). Bank Profitability: The Impact of Foreign Currency Fluctuations. Journal of Applied Business and Economics, 16(2), 98-104.

Isaac, L. (2015). Assessing the Impact of Exchange Rate Risk on Banks Performance in Nigeria. Journal of Economics and Sustainable Development, 6(6), 1-14.

Johansen, S. (1988). Statistical analysis of cointegration vectors. Journal of Economic Dynamics and Control, 12, 231-54. https://doi.org/10.1016/0165-1889(88)90041-3

Johansen, S. (1991). Estimation and Hypothesis Testing of Co-integration Vectors in Gaussian Vector Autoregressive Models. Econometrica, 59, 1551-1580. https://doi.org/10.2307/2938278

Johansen, S. (1994). The role of the constant and linear terms in cointegration analysis of nonstationary variables. Econometric Review, 13, 205-30. https://doi.org/10.1080/07474939408800284

Johansen, S., \& Juselius, K. (1990). Maximum likelihood estimation and inference on cointegration with application to the demand for money. Oxford Bulletin of Economics and Statistics, 52(2), 169-210. https://doi.org/10.1111/j.1468-0084.1990.mp52002003.x

Kemisola, O., Ademola, O., Olamide, J., \&Moses, O. (2016). Exchange Rate Volatility and Banks Performance: Evidence from Nigeria. IIARD International Journal of Economics and Business Management, 2(4), 1-11.

Lagat, C., \& Nyandema, D. (2016). The Influence of Foreign Exchange Rate Fluctuations on the Financial Performance of Commercial Banks Listed at the Nairobi Securities Exchange. British Journal of Marketing Studies, 4(3), 1-11. https://doi.org/10.20431/2349-0349.0411008

Manyo, T., Sabina, N., \& Ugochukwu, U. (2016). The Effect of Foreign Exchange Transaction on the Performance of Nigerian Banks. IJRDO-Journal of Business Management, 2, 139-154.

Merikas, G. (1999). The exchange rate exposure of Greek banking institutions. Managerial Finance, 25(8), 52-60. https://doi.org/10.1108/03074359910766118

Naceur, S. B. (2003). The Determinants of the Tunisian Banking Industry Profitability: Panel Evidence. Universite Libre de Tunis. Working Papers.

Ngan, T. (2015). Impact of exchange rate fluctuations on business risk of Joint Stock Commercial Banks: Evidence from Vietnam. Research Journal of Finance and Accounting, 6(4), 123-128.

Ngerebo, T. (2012). The impact of foreign exchange fluctuation on then intermediation of banks in Nigeria (1970 - 2004). African Journal of Business Management, 6(11), 3872-3879. https://doi.org/10.5897/AJBM09.113

Offiong, A., Riman, H., \& Akpan, E. (2016). Foreign exchange fluctuations and commercial banks profitability in Nigeria. Research Journal of Finance and Accounting, 7(18), 121-126.

Ongore, V., \&Kusa, G. (2013). Determinants of Financial Performance of Commercial Banks in Kenya. International Journal of Economics and Financial Issues, 3(1), 237-252.

Osuagwu, E. (2014). Determinants of Bank Profitability in Nigeria. International Journal of Economics and Finance, 6(12), 46-63. https://doi.org/10.5539/ijef.v6n12p46 
Otuori, O. H. (2013). Influence of exchange rate determinants on the performance of commercial banks in Kenya. European Journal of Management Sciences and Economics, 1(2), 86-98.

Pesaran, M. H., \& Smith, R. P. (1998). Structural analysis of cointegrating VARs. Journal of Economic Surveys, 12, 471-505. https://doi.org/10.1111/1467-6419.00065

Pesaran, M. H., Shin, Y., \& Smith, R. J. (2001). Bounds testing approaches to the analysis of level relationships. Journal of Applied Econometrics, 16, 289-326. https://doi.org/10.1002/jae.616

Phillips, P., \& Perron, P. (1988). Testing for a Unit Root in Time Series Regression. Biometrica, 75, 335-346. https://doi.org/10.1093/biomet/75.2.335

Ramadan, I. Z., Kilani, Q. A., \& Kaddumi, T. A. (2009). Determinants of bank profitability: Evidence from Jordan. International Journal of Academic Research, 3(4), 180-191.

Saona, P. (2016). Intra- and extra-bank determinants of Latin American Banks' profitability. International Review of Economics and Finance, 45, 197-214. https://doi.org/10.1016/j.iref.2016.06.004

Staikouras, C. K., \& Wood, G. E. (2004). The Determinants of European Bank Profitability. International Business \& Economics Research Journal, 3(6). https://doi.org/10.19030/iber.v3i6.3699

Taiwo, O., \& Adesola, O. (2013). Exchange rate volatility and bank performance in Nigeria. Asian Economic and Financial Review, 3(2), 178-185.

Westerlund, J. (2007). Testing for Error Correction in Panel Data. Oxford Bulletin of Economics and Statistics, 69, 709-748. https://doi.org/10.1111/j.1468-0084.2007.00477.x

Williams, H. (2018). An Empirical Investigation of the Impact of Exchange Rate Fluctuations on the Performance of Selected Listed Firms in Nigeria. Journal of Business Management and Economic Research, 2(3), 1-10. https://doi.org/10.29226/TR1001.2018.22

Wong, T., Wong, J., \& Leung, P. (2009). The Foreign Exchange Exposure of Chinese Banks. China Economic Review, 20(2) 174-182. https://doi.org/10.1016/j.chieco.2009.03.003

\section{Appendix A. Specification and diagnostic Tests}

\begin{tabular}{|c|c|c|c|c|c|}
\hline \multicolumn{6}{|c|}{ Heteroskedasticity Test for ROE Model } \\
\hline \multicolumn{6}{|c|}{ Heteroskedasticity Test: Breusch-Pagan-Godfrey } \\
\hline F-statistic & 0.16461 & \multicolumn{2}{|c|}{ Prob. F(4,56) } & \multicolumn{2}{|l|}{0.9554} \\
\hline Obs*R-squared & 0.70891 & \multicolumn{2}{|c|}{ Prob. Chi-Square(4) } & \multicolumn{2}{|l|}{0.9502} \\
\hline$\underline{\text { Scaled explained SS }}$ & 1.84528 & \multicolumn{2}{|c|}{ Prob. Chi-Square(4) } & \multicolumn{2}{|l|}{0.7642} \\
\hline \multicolumn{6}{|c|}{ Heteroskedasticity Test for LQTY Model } \\
\hline \multicolumn{6}{|c|}{ Heteroskedasticity Test: Breusch-Pagan-Godfrey } \\
\hline F-statistic & \multicolumn{2}{|c|}{2.414638} & Prob. F(4,56) & & 0.0595 \\
\hline Obs*R-squared & \multicolumn{2}{|r|}{8.973267} & Prob. Chi-Square(4) & & 0.0618 \\
\hline Scaled explained SS & \multicolumn{2}{|r|}{6.250747} & Prob. Chi-Square(4) & & 0.1812 \\
\hline \multicolumn{6}{|c|}{ Heteroskedasticity Test for ROA Model } \\
\hline \multicolumn{6}{|c|}{ Heteroskedasticity Test: Breusch-Pagan-Godfrey } \\
\hline F-statistic & \multicolumn{2}{|c|}{3.539370} & Prob. F(4,56) & & 0.0121 \\
\hline Obs*R-squared & \multicolumn{2}{|r|}{12.30954} & Prob. Chi-Square(4) & & 0.0152 \\
\hline Scaled explained SS & \multicolumn{2}{|r|}{5.541183} & \multicolumn{2}{|l|}{ Prob. Chi-Square(4) } & 0.2361 \\
\hline \multicolumn{6}{|c|}{ Serial Correlation test for ROE Model } \\
\hline \multicolumn{6}{|c|}{ Breusch-Godfrey Serial Correlation LM Test: } \\
\hline F-statistic & 4.604549 & \multicolumn{2}{|c|}{ Prob. F(2,54) } & \multicolumn{2}{|r|}{0.0142} \\
\hline Obs*R-squared & 8.887249 & \multicolumn{2}{|c|}{ Prob. Chi-Square(2) } & \multicolumn{2}{|r|}{0.0118} \\
\hline \multicolumn{6}{|c|}{$\underline{\text { Serial correlation test for ROA Model }}$} \\
\hline \multicolumn{6}{|c|}{ Breusch-Godfrey Serial Correlation LM Test: } \\
\hline F-statistic & 8.767344 & \multicolumn{2}{|c|}{ Prob. F(2,54) } & & 0.0005 \\
\hline Obs*R-squared & 14.95241 & & hi-Square(2) & & 0.0006 \\
\hline Serial Correlation tes & ГY Model & & & & \\
\hline Breusch-Godfrey Ser & lation LM Tes & & & & \\
\hline F-statistic & 18.28067 & & $(2,54)$ & 0.0000 & \\
\hline Obs*R-squared & 24.62687 & & hi-Square(2) & 0.0000 & \\
\hline
\end{tabular}




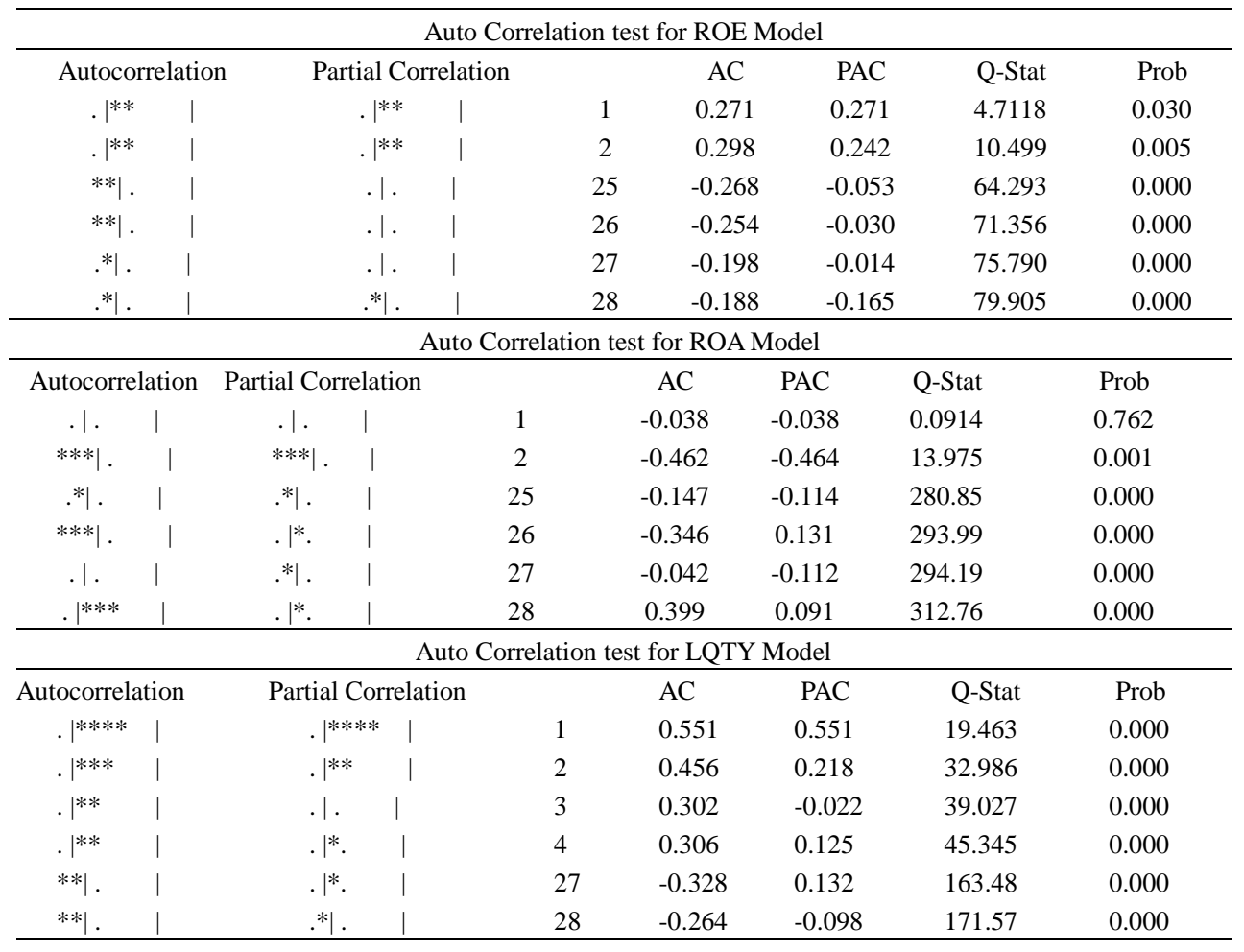

Researcher's E-views Output.

\section{Appendix B. Model's Statistics Outputs}

\begin{tabular}{|c|c|c|c|}
\hline \multicolumn{4}{|c|}{ ROE Model's Statistics Output } \\
\hline R-squared & 0.646821 & Mean dependent var & 0.455279 \\
\hline Adjusted R-squared & 0.607579 & S.D. dependent var & 0.090054 \\
\hline S.E. of regression & 0.056413 & Akaike info criterion & -2.788352 \\
\hline Sum squared resid & 0.171851 & Schwarz criterion & -2.546120 \\
\hline Log likelihood & 92.04473 & Hannan-Quinn criter. & -2.693419 \\
\hline F-statistic & 16.48283 & Durbin-Watson stat & 1.947246 \\
\hline Prob(F-statistic) & 0.000000 & & \\
\hline \multicolumn{4}{|c|}{ ROA Model's Statistics Output } \\
\hline R-squared & 0.608688 & Mean dependent var & $7.96 \mathrm{E}-06$ \\
\hline Adjusted R-squared & 0.580737 & S.D. dependent var & 0.307941 \\
\hline S.E. of regression & 0.199394 & Akaike info criterion & -0.308659 \\
\hline Sum squared resid & 2.226440 & Schwarz criterion & -0.135636 \\
\hline Log likelihood & 14.41409 & Hannan-Quinn criter. & -0.240850 \\
\hline F-statistic & 21.77706 & Durbin-Watson stat & 2.036447 \\
\hline Prob(F-statistic) & 0.000000 & & \\
\hline \multicolumn{4}{|c|}{ LQTY Model Statistics Output } \\
\hline R-squared & 0.854435 & Mean dependent var & 0.238379 \\
\hline Adjusted R-squared & 0.838261 & S.D. dependent var & 0.145435 \\
\hline S.E. of regression & 0.058489 & Akaike info criterion & -1.772781 \\
\hline Sum squared resid & 0.184734 & Schwarz criterion & -1.530549 \\
\hline Log likelihood & 61.06981 & Hannan-Quinn criter. & -1.677848 \\
\hline F-statistic & 52.82798 & Durbin-Watson stat & 1.956215 \\
\hline Prob(F-statistic) & 0.000000 & & \\
\hline
\end{tabular}

\section{Copyrights}

Copyright for this article is retained by the author(s), with first publication rights granted to the journal.

This is an open-access article distributed under the terms and conditions of the Creative Commons Attribution license (http://creativecommons.org/licenses/by/4.0/). 